\title{
The Relationship between Knowledge Management Processes and Workforce Agility in the Sri Lankan Banking Sector
}

\author{
K.A.D.T.D. Kuruppu ${ }^{1} \&$ M.H.A. Egodawele ${ }^{2}$ \\ ${ }^{1,2}$ Department of Management Studies \\ Faculty of Management \\ University of Peradeniya \\ Peradeniya \\ SRI LANKA
}

\begin{abstract}
kurupputd@gmail.com ${ }^{1}$, mekhala.egodawele@gmail.com ${ }^{2}$
"The critical feature of a knowledge workforce is that its workers are not labor, they are capital." - "They're Not Employees; they're People," Drucker (1998)
\end{abstract}

\begin{abstract}
The knowledge asset was highlighted as the key strategic weapon in the postindustrial societies to achieve the competitive edge. Sri Lanka is gradually moving towards a post-industrial society context, which will increase the domain value centered on knowledge management and knowledge worker's agility. Nonetheless, this study serves as a prelude to investigating the relationship of knowledge management practices on worker agility in the Sri Lankan banking sector. Workforce agility has received much interest in the manufacturing industry, but it has been overlooked in the service industry. As a response, the authors develop research questions to assess the relationship between proactive agility and flexible agility in knowledge management processes (knowledge creation, acquisition, sharing, and application) in the banking industry. The banking industry was chosen specifically because it is prone to change on a daily basis, and employees were expected to adjust their agile behavior. Two hypotheses were constructed for this purpose, and both hypotheses were failed to reject based on the correlation analysis and thus the findings of the study confirmed that knowledge management has a significant positive relationship with proactive agility and flexible agility. For this quantitative, deductive study, a systematic literature review was conducted. Existing knowledge was used to create a conceptual framework that addresses in the gaps in current research. The findings of the study emphasize the significance of top management's involvement and strategic direction in fostering a strong knowledge management culture, which has a significant important role in the long run to sustain an agile workforce.
\end{abstract}

Keywords-: Flexible Agility, Knowledge, Knowledge Management, Proactive Agility, Workforce Agility 


\section{INTRODUCTION}

The contemporary business environment has turned out to be "volatile, uncertain, complex, and ambiguous (VUCA)" in nature with an inherent plethora of opportunities and threats while portraying a network of organizations that regularly "appears, develops, or disappears" (Munteanu, Bibu, Nastase, Cristache \& Matis, 2020). The novel economic world-order has resulted in the change in consumption patterns, ceasing of boundaries among countries, technological development, globalization and deregulation (Hu \& Liden, 2015; Khoo, 2011). Hence, a number of business organizations are in quest of conquering the environmental turbulence and uncertainty effectively (Almahamid, 2018) and the conventional strategies and hierarchical models are found to be obsolete and insufficient to address these changes and align with the present-day business environment (Braun, Hayes, DeMuth \& Taran, 2017). The modern business organizations are challenged to continuously adapt to the increasing demands rapidly and entirely (Munteanu et al., 2020). In order to sustain in the turbulent environment, the organizations tend to instill empowerment, updated technology, work organizations, virtual organizations, cross training and communication with the aim of instilling agility within themselves (Almahamid, 2018).
(Gartside et al., 2014) assert that organizations adopt agility as an "enterprise-wide strategy" in order to sustain within the dynamic and competitive business environment. It enables organizations to cope with business environment turbulence. An accelerated level of agility has been portrayed as a gratifying capability that allows the rapid utilization of business opportunities (Hatzijordanou, Bohn \& Terzidis, 2019). Organizational agility resonates the potentiality that helps an organization to sustain and perform within a dynamic and unpredictable environment (Vinodh, Aravindraj, Pushkar \& Kishore, 2012). It is a strategy that enables business organizations to sustain on a "borderless battlefield" (Holbeche, 2018; Storme, Suleyman, Gotlib \& Lubart, 2020). A number of aspects of agility have been investigated by many scholars, and they include agile software development (Krancher \& Luther, 2021), agile manufacturing (Potdar et al., 2017) and agile workforce (Storme et al., 2020, Muduli, 2016). Agility covers a range of criteria such as innovation, customization, speed, adaptability, quality, flexibility, proactivity, profitability and knowledge (Qin \& Nembhard, 2015).

Today, the achievement of agility has become challenging without 
an agile workforce and in fact, workforce agility can be cited as a multifaceted and a complex concept (Muduli \& Pandya, 2018). Workforce agility is paramount for the sustenance of the contemporary business organizations that are based in an unprecedented and fast paced business world. The notion; agile workforce has been subjected to investigation in order to formulate agile organizations that undergo "superior environmental responsiveness" amidst change (Muduli, 2013) and it is a powerful approach to respond to the environmental changes both proactively and reactively (Almahamid, 2015). Breu, Hemingway, Strathern and Bridger (2002) define workforce agility as a concept that relates to "environmental responsiveness" to the volatility in the market which also resonates the perception put forward by Qin and Nembhard (2015), who cited the concept as "knowledge workers". Muduli (2016) portrayed agile workforce as workers instilled with a wide vision who can cope with volatile environments and exploit new opportunities. In fact, the father of knowledge management; Peter Drucker, who initially coined the term "knowledge workers", had already predicted that the knowledge workers will turn out to be the most precious asset of an organization in the 21 st century owing to their accelerated levels of creativity and productivity (Drucker, 1999).
As the authors assess the notion; workforce agility, two dimensions namely, proactive (Parker, Bindl \& Strauss, 2010; Sherehiy, 2008) and flexible (Heckler \& Powell, 2016) will be utilized for in study to investigate the impacts of knowledge management processes. Proactive agility is the prediction of issues that relate to change, formulation of solutions and the resolution of those issues (Chonko \& Jones, 2005) while the dimension; flexible resonates the potential to attain contradictory objectives and receive distinct products at similar levels and this is required to be instilled in employees in order to cope with distinct activities and groups simultaneously (Sherehiy, 2008).

The concept; knowledge management received considerable attention during the last decade and the $21^{\text {st }}$ century saw it becoming an "electromotive force" that drives the economic, social and educational development in any country (Igbinovia \& Ikenwe, 2018). Knowledge Management is represented by the requirement to manage knowledge in a company as an asset (Ghani, 2009) and Kucza (2001) asserts that knowledge management is the management of the processes of creating, storing and sharing knowledge coupled with other related tasks. (Omotayo, 2015) states that knowledge management is crucial for the companies that are aiming at attaining a sustainable strategic competitive edge. The knowledge 
management processes can be showcased as the visible activities of the organizations that relate to knowledge management and other business processes expedited in those entities for the creation, storage, transfer and application of knowledge (Rasoulinezhad, 2011).

The attainment of a competitive edge is a considerable challenge for the contemporary knowledge intensive companies. Knowledge management can be cited as an effective approach utilized by the contemporary organizations as they make several attempts to survive amidst environmental turbulence. Agility in business organizations demands to understand "where" and "why" the changes occur and "how" the organization needs to react, and this is facilitated by knowledge management processes within these entities ( $\mathrm{Su}, 2011)$. As such, knowledge enables the resolution of the current challenges in the digital era (Al-Khouri, 2014) and it has been recognized as a pivotal strategic resource that enables organizations to secure competitive advantage within a dynamic market environment since the early nineties (Spender, 1998) and many organizations have begun to consider the significance of knowledge reservation (Gill, 2009). Today, the knowledge management processes; knowledge creation, acquisition, sharing and application facilitate the survival of business organizations within the uncertain environmental changes and their operations with a competitive edge (Almahamid, 2015).

Knowledge creation can be cited as an ongoing process of vigorous interplay between tacit knowledge (Nonaka \& Takeuchi, 1996) and it is the potential of a company to produce new knowledge, solutions and new ideas that are creative in nature using technology with the aim of systematically handling the organizational tasks (Andreeva \& Kianto, 2011). Knowledge acquisition improves the full span of external knowledge of a firm by accelerating the prospect of merging external and internal knowledge, which will result in innovative solutions for the organization (Yli-Renko et al., 2001). Knowledge sharing is the foundation for the accomplishment of the company and it acts as a roadmap that aids in their survival (Witherspoon, Bergner, Cockrell, and Stone, 2013) Boateng and Agyemang (2015) portray that knowledge application allows organizations to utilize knowledge to enhance their operations, produce novel knowledge and formulate novel products.

The companies that manage their knowledge under three pillars; people, technology and process, effectively will undergo sustainable development and growth (Igbinovia \& Ikenwe, 2018).

Business organizations, particularly banks are facing 
fierce competition often owing to phenomena such as high market pressures, innovation and globalization (Mousavizadeh, Harden, Ryan \& Windsor, 2015). Workforce agility can be elucidated as a notion of paramount importance for the banking institutions in the contemporary world as the needs of clientele are subjected to changes at a rapid pace (Ajgaonkar, Neelam \& Wiemann, 2021). These institutions face a plethora of issues as they struggle to face the effects of global economic depression and recession via the retention of a loyal and steady clientele in the financial stage Ollusolla, Ollodude, Bollanlle \& Olladejjo. (2013). As these knowledge intensive organizations are equipped with knowledge workers, a number of attempts have been made by the banks to implement knowledge management systems to expedite their strategies and enhance performance (Zack, McKeen \& Singh, 2009).

The banking sector in Sri Lanka is undergoing major transformations, which are accompanied by technological, behavioral, and societal changes. Having automated teller machines (ATMs) used to be a major orderwinning element. However, with today's changes, having automated teller machines does not guarantee order winning characteristics. Through digitalization, today's consumers seek better ways to deal with their work routines. As a result, all stakeholders, including bankers, accept agile behaviour.

(Aghion \& Griffith, 2008) assert that a competitive market environment allows efficient resource allocation that enhances productivity and growth of national economy. Sri Lanka also undertook an extensive liberalization process that portrayed a break with the protectionist policies followed for many decades (Athukorala \& Rajapatirana, 2000), to establish a competitive banking market and it was the first South Asian nation to engage in economic liberalization. This marked the introduction of a number of reforms in the financial sector to boost economic growth. The Sri Lankan banking sector consists of the Licensed Commercial Banks (LCBs) and Licensed Specialized banks (LSBs). This industry dominates the financial sector of the country while accounting for the highest portion of the overall assets in the financial system (CBSL, 2018). Hence, banking institutions undoubtedly play a pivotal role in the financial system of Sri Lanka and their effectiveness is paramount for the economic development of the country. It should be noted that in the contemporary Sri Lankan banking sector, the entities are required to attain organization agility particularly by formulating an agile workforce that allows them to cope with environmental turbulence. 


\subsection{Problem statement}

Albeit, human resources have been cited as the major source of competitiveness and drivers of change and agility in organizations by many scholars (Munteanu et al., 2020), a few studies have been conducted to address the concept; workforce agility (Storme et al., 2020). Furthermore, there have been much discussion in academia in workforce agility and its enablers in the context of the manufacturing organizations across the world (Sherehiy \& Karwowski, 2014; Alavi \& Wahab, 2013). However, research on the impacts of the KM processes on workforce agility within the service organizations in the banking institutions in Sri Lanka is extremely rare. Hence, this study aims at exploring the relationship of the knowledge management processes namely, knowledge creation, acquisition, sharing and application on workforce agility in the banking institutions in Sri Lanka. Contributing to the discourse of knowledge management processes and their impact on workforce agility, this paper aims at assessing the effect of knowledge management processes (creation, acquisition, sharing and application) on the proactive and flexible workforce agility in the banking sector in Sri Lanka.

The study aims at addressing the above gap in relation to workforce agility by formulating the following research problems.

1. Do knowledge management processes (Creation, Acquisition, Sharing, and Application) relate with Proactive workforce agility in the banking institutions in Sri Lanka?

2. Do knowledge management processes (Creation, Acquisition, Sharing, and Application) relate with flexible workforce agility in the banking institutions in Sri Lanka?

\subsection{Research hypothesis}

Based on the above research questions and conceptual framework (Figure 1), the authors hypothesize that knowledge management processes have an impact on workforce agility at the banking institutions in Sri Lanka. Thus, in order to summarize the arguments articulated based on the previous research, the authors have formulated the following research hypotheses as follows:

H1: There is a significant relationship between knowledge management processes (Creation, Acquisition, Sharing, and Application) and proactive workforce agility.

$\mathrm{H} 2$ : There is a significant relationship between knowledge management processes (Creation, Acquisition, Sharing, and 
Application) and flexible workforce agility.

\subsection{Contribution}

It is crucial that we extend our understanding to the banking institutions and it will aid in preventing a prospective loss in research opportunities in relation to the knowledge management driven workforce agility in these institutions that play a pivotal role in emerging economies as engines of innovation. This study measures the relationship between the independent variables that cover the four knowledge management processes namely knowledge creation, acquisition, sharing and application and the dependent variables of workforce agility (proactive and flexible) which will contribute to the literature by exploring the impacts of knowledge management processes on the workforce agility in the Sri Lankan banking institutions. Furthermore, this study can be cited as one of the important pieces of literature that assess the workforce agility within the banks specially in the context of a developing country like Sri Lanka and it will help the Sri Lankan banking institutions to be aware of the adoption and application of the knowledge management processes in future while recognizing the significance of these processes in stimulating workforce agility. This study will also feature useful findings that may provide the Sri Lankan banking sector with effective recommendations that will aid them in the adoption of the concepts like knowledge management and workforce agility as they consider enhancing the work force related processes to accelerate performance within their entities

\section{METHODS}

As this study aims at investigating the relationship between the knowledge management processes; knowledge creation, acquisition, sharing and application and the workforce agility at the banking institutions in Sri Lanka, it follows a quantitative research paradigm and it enables the prediction of causal relationships and the statistical inference of the findings to the overall population (Sarantakos, 2005). Quantitative research methods explain a problem or an event via the collection of numerical data and analyzing them with the help of mathematical methods; specially statistics (Aliaga \& Gunderson, 2002). A deductive approach is followed in the study as it aims at testing a hypothesis and hence, it is suitable to be dealt with quantitative data. Creswell and Plano Clark (2007) assert that a deductive researcher works from "top to bottom" from a theory to hypothesis in order to collect data to modify or add to the theory.

The population of this study consisted of the front line and middle line managerial level employees of the entire banking sector of Sri Lanka. It follows simple random sampling which is 
a probability sampling technique. The population of the study covers the overall Sri Lankan banking sector while the sample of the study consists of all commercial and public banks based in Sri Lanka. Data collection was conducted through a structured questionnaire which consisted of 46 questions relating to demographic information such as gender, age, district, sector and position and standard information like knowledge management processes and the dimensions of workforce agility. A likert scale of 5 point was used in the questionnaire with five response levels (Strongly Disagree $=1$, Disagree $=2, \quad$ Neutral $=3$, Agree $=4$, Strongly Agree=5. SPSS (Statistical Package for the Social Sciences) version 23 was used, to statistically analyze the results and in addition, the correlation test was used to assess the relationship between the knowledge management processes and the dimensions of workforce agility. The study finds a positive, significant correlation between the two variables. To analyze the demographic variables such as age, gender, district, sector and position, the descriptive method was employed. Inferential statistics were employed in conjunction with a correlation study to investigate the relationship. Due to the quantitative character of the responses, SPSS 21 was used to analyses data.

\section{RESULTS}

At the initial stage 524 questionnaires were distributed and only 277 were received back. From 277 responses, 03 responses were neglected from the study since it carries missing values. Therefore, for the study purpose 274 responses were analysed.

According to the demographic analysis shown in table 01 , there was a minor difference in the representation of male and female respondents. The male representation was 51.5 percent, while the female representation was 48.5 percent. The highest answer rate was obtained from Gamapaha district, at 21.5 percent, and the lowest response rate was recorded in Hambanthota, at 2.2 percent. The private sector employed the majority of the respondents, accounting for 51.8 percent of the total. In the study, $75.9 \%$ of firstline employees are represented, with the remaining 24.1 percent made up of the middle-level personnel.

Despite the study results, the normal distribution of variables was utilized (KolmogorovSmirnov $\mathrm{Z}$ test) to check the absence of study data from statistical difficulties that could adversely affect the outcomes of the study hypotheses. This indicates normality distribution for variable and table 02 shows that the study results. $(\mathrm{P}>0.05)$

Cronbach's alpha $(\alpha)$ was utilized to assess the construct's reliability 
in this study. Table 3 reveals that the Cronbach' alpha value ranges from 0.669 to 0.88 , indicating that the study variables have a high level of internal consistency.

There is no statistically significant difference in agility between male and female employees, according to the independent samples test results based on gender, as shown in table 04

There is a considerable difference between workforce agility in the private and public sectors, according to the independent samples test results based on sector provided in table 05 . Employees in the private sector are agile than those in the public sector, according to the findings of the post hoc study.

There is no substantial difference in workforce agility between first line and middle level employees, according to table 06, independent samples test results based on job position.

According to table 07, there is a substantial variation in worker agility between different age groups. According to the post hoc study results $25-30$ yrs. and 31 to 35 yrs. age categories have a high level of agility.

There is no significant variation in workforce agility between different districts, according to table 08, the one-way ANOVA findings based district.

Table 09 shows that the highest mean (4.52) out of (5) for item (4) " Top management is well aware of the banks needs for knowledge in different aspects of its daily activities " by high agreement degree, then for item (3) " The bank works constantly to update the different kind of knowledge it has. " by high agreement degree. The highest agreement degree was (Means 4.28) and the lowest agreement degree was (3.8) for item (5) " The bank works to support the creative ideas of its own. " by a moderate level of agreement

Table 10 on descriptive statistics of knowledge sharing shows that the highest mean (4.72) out of (07) was achieved by high agreement degree for item (4) " The bank encourages the employees to develop their knowledge." and the lowest mean (3.48) was achieved by moderate agreement degree for item (7) " The bank provides mechanisms for receiving views and suggestions among employees "

When analyzing the mean of knowledge sharing, table 11 shows that the highest means reached (4.28) out of (06) for item (6) "Promote a supportive environment for knowledge exchange of ideas among all employees. " by high agreement degree, and the lowest means was (3.28) for item (3) "We always analyze unsuccessful organizational endeavors and communicate the lessons learned widely." by moderate agreement degree

Table 12 shows that the highest mean of knowledge application 
was (4.52) out of (04) for item (1)

" There is an initiative to deliver the knowledge that available to all employees" by high agreement degree, and the lowest mean was (3.46) for item (4) " The bank encourages its employees to benefit from its own knowledge inventory." by lower agreement degree.

Table 13 shows that the highest mean (4.76) out of (06) for item (3) "I look for opportunities to improve at work." by high agreement degree, and the lowest means (3.48) for item (1) "I am able to solve new and complex problems at work." by moderate agreement degree when analyzing the mean of variable "proactive."

Table 14 shows that the highest means were (4) out of (07) for item (2) "I like to change old ways of doing things." by high agreement degree, and the lowest means were (2.45) for item (3) "I am able to perform the job without knowing the total picture." by poor agreement degree when analyzing the mean of variable "flexible."

According to table 15, there is a strong positive correlation between knowledge management and proactive agility (Pearson Correlation 0.878) and flexible agility (Pearson Correlation 0.662). Albeit all two study hypotheses are failed to reject based on the correlation analysis provided in table 16 , as it becomes statistically significant at the 0.01 significant level.

\section{DISCUSSION}

The effects of demographic variables on workforce agility in Sri Lanka's banking industry was first explored in this study. Gender, age, employment position, district, and sector were all assessed for significant variations between and among different demographic groupings. Age and sector differences were found to be significant between groups.

When it comes to the age element, it has a direct impact on workforce agility because generation $\mathrm{Z}$ is one of the most influential age groups in modern settings as well as in this study itself. According to the post hoc test results, the age groups of 25 to 30 and 31 to 35 showed greater workplace agility. Generations X (born between the mid-1960s and the early 1980s) and Y (born between the 1980s and the year 2000) make up Generation Z. Based on Bascha (2011) research, this research finding is further refined. They discovered that generation $\mathrm{Z}$ values transparency, self-reliance, flexibility, and personal freedom in the job, and that they are more agile. Generation Z, it should be noted, is the education generation, and as a result, they prefer more agile characteristics. In today's workplace, Gen X and Gen Y are having the most important impact and they are in charge of the entire workplace's 30 percent of the people (Gaidhani, Arora \& Sharma, 2019). 
Employees in the private sector are more agile for a variety of reasons, including their compensation and performance evaluation systems. Their promotions and other rewards are precisely aligned with their agile initiatives to boost the entire organization's efficiency and uplifting the standards of knowledge based culture.

Gender, job position and district, on the other hand, did not show any significant disparities. According to the researchers, previous studies on the subject have not revealed such disparities.

Following the demographic studies, the study found the most and least significant issues in workforce agility in banking industry in Sri Lanka. Moving on to variables that were listed as strongly agreed issues, most respondents emphasized the importance of "Top management is well aware of the bank's demands for information in various facets of its everyday activity" in the knowledge creation category. Employees feel top management has an unavoidable responsibility to instill a knowledge creation culture within the firm via productive strategic decisions because top management is accountable for executing the organization's strategic plan. Savva and Stylianou (2016) also emphasize senior management's role in enabling a knowledgecreating culture within the firm through strategy and leadership.
When it came to the study's findings on knowledge acquisition, the highest mean was "The bank encourages employees to enhance their expertise." When talking with employees, they regularly mentioned workshops, webinars, and programs that give them with fresh ways to learn. In most cases, banks attempt to arrange guest lectures from notable industry professionals in order to keep up the momentum with current industry trends. Further researchers identified that most banks have provided flexible loan rates and sufficient financial support for higher education options such as master's degrees and postgraduate degrees. This might be seen as a positive step in which staff were provided several opportunities to learn in a systematic manner.

The highest mean recorded for "Promote a favorable environment for knowledge exchange of ideas among all employees," according to the findings of the knowledge sharing survey. KM enablers, according to Savva \& Stylianou (2016), should include organizational structure, strategy, and leadership, technology infrastructure, culture, organizational processes, and measurement to develop strong organizational settings to share knowledge. Rusil and Tasmin (2010) go on to say how important it is to improve technical infrastructure in order to facilitate good knowledge sharing in the twenty-first century, because technology is an inextricable 
aspect of the discipline of knowledge sharing.

According to the knowledge application, the highest mean recorded for the item "There is an initiative to deliver knowledge that is available to all employees." In this environment, most banks have made on-the-job training a priority in order to train juniors and newcomers. As a result, most banks allow newcomers to learn from their more experienced colleagues by collaborating.

The highest ranked item of the variable "proactive" is "I search for possibilities to improve at work."" The majority of employees are eager to gain new skills and do their best to improve existing systems.

"I like to change old methods of doing things," reported the highest mean for the variable 'flexible."' Because the majority of respondents are from generation $\mathrm{Z}$, they have a contradictory view about traditional procedures. They frequently seek out novel and innovative ways to do tasks (Gaidhani, 2019). The item "I am able to accomplish the task without understanding the entire picture" had the lowest mean rating for flexibility. This is an important study finding because it emphasizes the necessity of providing employees with a holistic understanding of their job roles. In most modern businesses, the matrix structure or project structure is used, in which two or more functional areas collaborate to achieve the intended goals.
Employers prefer to know the big picture because it gives them more flexibility in how they structure their job roles. If they just pursue knowledge in one area, it will have a negative impact on their flexibility and overall agility.

Two hypotheses were constructed for the study's objective, and both hypotheses failed to reject. There was a substantial favorable association between proactive agility and flexible agility and knowledge management.

\section{CONCLUSION}

Previously, workforce agility in Sri Lanka was mostly oriented on manufacturing perspectives, with the service sector being rather somewhat disregarded. There are few empirical studies to identify these concerns among contemporary knowledge management reforms followed by workforce agility in service sectors, particularly in the banking industry.

As a result, problems remain, and this study investigates how knowledge management practices relates with employee agility in the banking industry. Albeit a structured questionnaire was established based on a complete literature research and improved with expert input in order to meet the main purpose of analyzing the opinions of the relationship that exists between knowledge management and workforce agility. We were able to secure 47 usable questionnaires. 
After determining the demographic representation of the sample using descriptive statistics, the impact of demographic aspects of the KM process on workforce agility was studied. In terms of age and the sector they represent, there was a statistically significant difference.

Some of the conclusions from this investigation were deemed notable. Because the majority of employees in today's companies are from generation $\mathrm{Z}$, and thus age has a huge impact on workforce agility.

Following the preceding analyses, the data was subjected to a mean ranking analysis to determine which issue statements were most agreed with and which were most disagreed with.

The conclusions of this study are expected to have important policy ramifications, notably in strategic planning reforms in knowledge management practices of Sri Lankan banking industry. Because knowledge management is still a new concept in Sri Lankan corporate culture, senior management bears a significant amount of responsibility for sustaining a KM-enabling culture within the business through the implementation of proper longterm strategic policy framework. This is also emphasized by survey respondents, who state that senior management should be aware of the bank's expertise requirements in all elements of its everyday operations. Then, in the long run, it will aid in the creation of an agile workforce.

Based on the study's findings, the following recommendations can be made to the Sri Lankan banking system.

Companies should support this through brainstorming camps, lectures, and webinars so that upper-level management is equipped to employ $\mathrm{KM}$ procedures in their everyday performance. To instill a knowledge-driven culture within the organization, institutional assistance should be provided. Encourage all employees to share their knowledge and relevant information with their co-workers at all levels.

One limitation of this study is that it only evaluated one group of stakeholders, namely employees, and data gathering is restricted owing to the Covid 19 epidemic.

In future research, it is advised that the research scope be expanded to include additional service categories such as health care, education, and so on, as well as a larger sample size for the analysis. 


\section{APPENDIX}

Figure 1: Conceptual

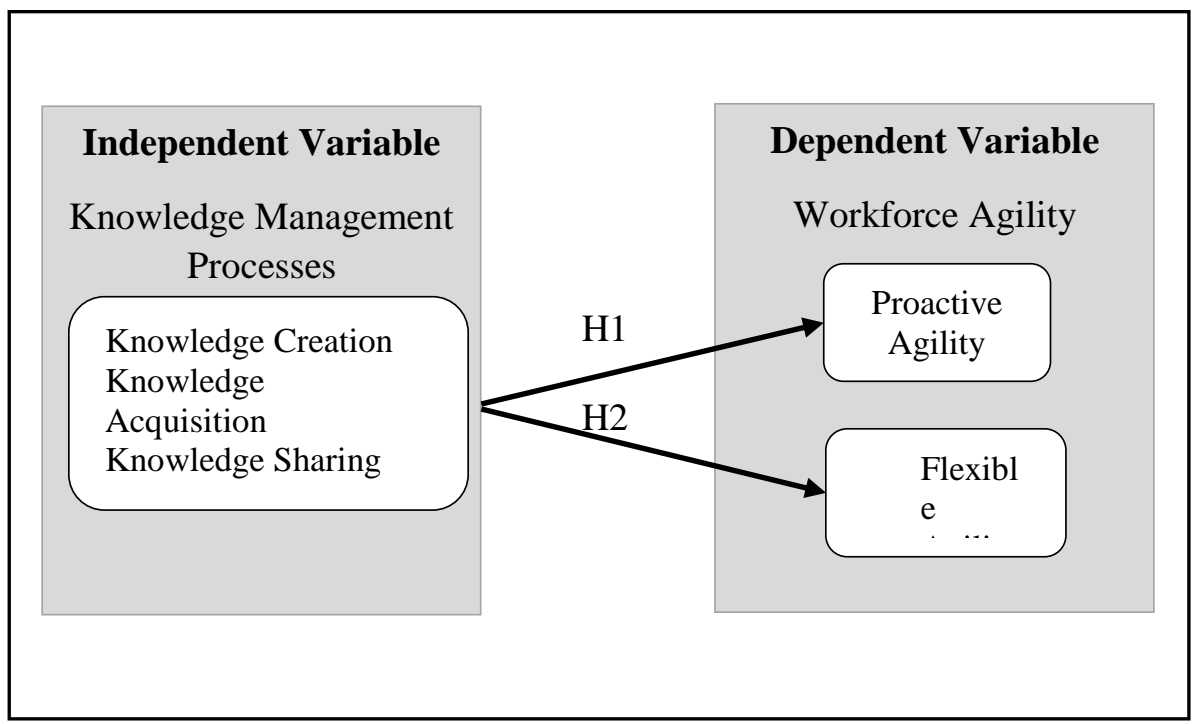

Source: Author's elaboration based on the literature

Table 1: Demographic variables

\begin{tabular}{|l|l|c|c|}
\hline Demographic & \multicolumn{1}{|c|}{ Categories } & Frequency & $\begin{array}{c}\text { Cumulative } \\
\text { Percent }\end{array}$ \\
\hline \multirow{4}{*}{ Gender } & Female & 133 & 48.5 \\
\cline { 2 - 4 } Age & Male & 141 & 51.5 \\
\hline \multirow{5}{*}{ District } & $25-30$ yrs. & 132 & 48.2 \\
\cline { 2 - 4 } & 31 to 35 yrs. & 23 & 8.4 \\
\cline { 2 - 4 } & 36 to 40 yrs. & 54 & 19.7 \\
\cline { 2 - 4 } & Above 40 yrs. & 65 & 23.7 \\
\cline { 2 - 4 } & Ampara & 23 & 8.4 \\
\cline { 2 - 4 } & Anuradhapura & 19 & 6.9 \\
\cline { 2 - 4 } & Badulla & 24 & 8.8 \\
\cline { 2 - 4 } & Colombo & 30 & 10.9 \\
\cline { 2 - 4 } & Galle & 10 & 3.6 \\
\cline { 2 - 4 } & Gampaha & 6 & 21.5 \\
\cline { 2 - 4 } & Hambanthota & 14 & 2.2 \\
\cline { 2 - 4 } & Kaluthara & 16 & 5.1 \\
\cline { 2 - 4 } & Kandy & 8 & 3.8 \\
\cline { 2 - 4 } & Kaluthara & 12 & 2.9 \\
\cline { 2 - 4 } & Kegalle & & 2.9 \\
\cline { 2 - 4 } & Mathale & 8 & \\
\cline { 2 - 4 } & Mathara & & 3.3 \\
\hline
\end{tabular}


Kuruppu K. A.D.T.D., Egodawele M.H.A.

Wayamba Journal of Management 12 (2)

\begin{tabular}{|l|l|c|c|}
\hline \multirow{4}{*}{ Sector } & Monaragala & 8 & 2.9 \\
\cline { 2 - 4 } & Nuwara Eliya & 15 & 5.5 \\
\cline { 2 - 4 } & Polonnaruwa & 13 & 4.7 \\
\hline \multirow{2}{*}{ Position } & Private & 142 & 51.8 \\
\cline { 2 - 4 } & Public & 132 & 48.2 \\
\cline { 2 - 4 } & First level employees & 208 & 75.9 \\
\cline { 2 - 4 } & Middle level employees & 66 & 24.1 \\
\hline
\end{tabular}

Source: Survey data ,2021

Table 2: Test of Normality

\begin{tabular}{|c|c|c|c|}
\hline Item & $\begin{array}{l}\text { Kolmogorov- } \\
\text { Smirnov }\end{array}$ & Sig & Result \\
\hline Knowledge Creation & .897 & 0.785 & \multirow{6}{*}{$\begin{array}{c}\text { Follows a } \\
\text { normal } \\
\text { distribution } \\
* \mathrm{P}>.05\end{array}$} \\
\hline Knowledge Acquisition & .697 & 0.851 & \\
\hline Knowledge Sharing & 1.6978 & 0.698 & \\
\hline Knowledge Application & 1.879 & 0.097 & \\
\hline Proactive & 1.697 & 0.501 & \\
\hline Flexible & 1.968 & 0.987 & \\
\hline
\end{tabular}

Source: Survey data ,2021

Table 3: Reliability test

\begin{tabular}{|l|c|}
\hline Item & Cronbach's alpha \\
\hline Knowledge Creation & 0.88 \\
\hline Knowledge Acquisition & 0.71 \\
\hline Knowledge Sharing & 0.75 \\
\hline Knowledge Application & 0.69 \\
\hline Proactive & 0.75 \\
\hline Flexible & 0.81 \\
\hline
\end{tabular}

Source: Survey data ,2021

Table 04: independent samples test result on sector

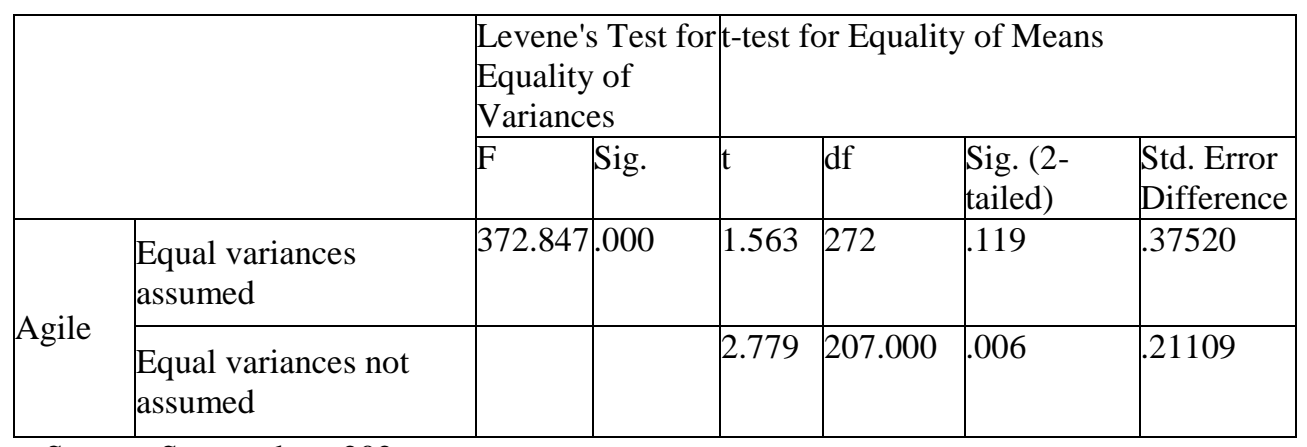

Source: Survey data ,202 
Table 05: independent samples test result on sector

\begin{tabular}{|c|c|c|c|c|c|c|c|c|}
\hline & \multicolumn{2}{|c|}{$\begin{array}{l}\text { Levene's Test for } \\
\text { Equality of } \\
\text { Variances } \\
\end{array}$} & \multicolumn{5}{|c|}{ t-test for Equality of Means } \\
\hline & & F & Sig. & $t$ & df & $\begin{array}{l}\text { Sig. (2- } \\
\text { tailed) }\end{array}$ & $\begin{array}{l}\text { Mean } \\
\text { Difference }\end{array}$ & \begin{tabular}{|l} 
Std. Error \\
Differenc \\
e
\end{tabular} \\
\hline \multirow{2}{*}{ Agile } & $\begin{array}{l}\text { Equal variances } \\
\text { assumed }\end{array}$ & $\begin{array}{l}957520.92 \\
2\end{array}$ & .000 & -6.830 & 272 & .000 & -2.03521 & .29799 \\
\hline & $\begin{array}{c}\text { Equal variances not } \\
\text { assumed }\end{array}$ & & & -6.594 & $\begin{array}{l}135.94 \\
5\end{array}$ & .000 & -2.03521 & .30867 \\
\hline
\end{tabular}

Source: Survey data ,2021

Table 06: independent samples test result on job position

\begin{tabular}{|c|c|c|c|c|c|c|c|c|}
\hline & \multicolumn{2}{|c|}{$\begin{array}{l}\text { Levene's Test for } \\
\text { Equality of } \\
\text { Variances }\end{array}$} & \multicolumn{5}{|c|}{ t-test for Equality of Means } \\
\hline & & $\mathrm{F}$ & Sig. & $\mathrm{t}$ & df & $\begin{array}{l}\text { Sig. (2- } \\
\text { tailed) }\end{array}$ & $\begin{array}{l}\text { Mean } \\
\text { Difference }\end{array}$ & $\begin{array}{l}\text { Std. Error } \\
\text { Difference }\end{array}$ \\
\hline \multirow[b]{2}{*}{ Agile } & $\begin{array}{c}\text { Equal } \\
\text { variances } \\
\text { assumed } \\
\end{array}$ & 372.847 & .059 & 1.563 & 272 & .119 & .58654 & .37520 \\
\hline & $\begin{array}{c}\text { Equal } \\
\text { variances not } \\
\text { assumed }\end{array}$ & & & 2.779 & 207.000 & .006 & .58654 & .21109 \\
\hline
\end{tabular}

Source: Survey data ,2021

Table 07: One-way ANOVA results based age

\begin{tabular}{|l|l|l|l|l|l|}
\hline & Sum of Squares & df & Mean Square & F & Sig. \\
\hline Between Groups & 1111.757 & 9 & 123.529 & 39.581 & .000 \\
\hline Within Groups & 823.922 & 264 & 3.121 & & \\
\hline Total & 1935.679 & 273 & & & \\
\hline
\end{tabular}

Source: Survey data ,2021 
Table 08: One-way ANOVA results based district

\begin{tabular}{|l|l|l|l|l|l|}
\hline & Sum of Squares & df & Mean Square & F & Sig. \\
\hline Between Groups & 1047.448 & 15 & 69.830 & 20.283 & .097 \\
\hline Within Groups & 888.231 & 258 & 3.443 & & \\
\hline Total & 1935.679 & 273 & & & \\
\hline
\end{tabular}

Source: Survey data ,2021

Table 09: Descriptive statistics for Knowledge Creation

\begin{tabular}{|l|r|r|r|r|r|}
\hline \multicolumn{1}{|l|}{ Knowledge Creation } & Mean & \multicolumn{1}{l|}{$\begin{array}{l}\text { Std. } \\
\text { Deviation }\end{array}$} & Variance & Skewness & Kurtosis \\
\hline $\begin{array}{l}\text { The Bank regularly monitors the } \\
\text { renewable knowledge that comes } \\
\text { from the various sources. }\end{array}$ & 4 & 0.695 & 0.484 & 1.369 & -0.919 \\
\hline $\begin{array}{l}\text { The bank regularly monitors the } \\
\text { available knowledge that comes } \\
\text { from the various sources. }\end{array}$ & 4 & 0.695 & 0.484 & 1.269 & -0.919 \\
\hline $\begin{array}{l}\text { The bank works constantly to } \\
\text { update the different kind of } \\
\text { knowledge it has. }\end{array}$ & 4.24 & 0.428 & 0.184 & 1.219 & -0.519 \\
\hline $\begin{array}{l}\text { Top management is well aware } \\
\text { of the banks needs for } \\
\text { knowledge in different aspects } \\
\text { of its daily activities }\end{array}$ & 4.52 & 0.501 & 0.251 & -0.073 & -2.009 \\
\hline $\begin{array}{l}\text { The bank works to support the } \\
\text { creative ideas of its own. }\end{array}$ & 3.8 & 0.849 & 0.72 & 0.404 & -1.495 \\
\hline
\end{tabular}

Source: Survey data ,2021 
Table 10: Descriptive statistics for Knowledge Acquisition

\begin{tabular}{|l|r|r|r|r|r|}
\hline & Mean & \multicolumn{1}{|l|}{$\begin{array}{l}\text { Std. } \\
\text { Deviation }\end{array}$} & Variance & Skewness & Kurtosis \\
\hline $\begin{array}{l}\text { There is support for good and } \\
\text { creative knowledge to develop } \\
\text { competitive advantage }\end{array}$ & 4.04 & 0.72 & 0.519 & -0.055 & -1.062 \\
\hline $\begin{array}{l}\text { There is sector inside the bank } \\
\text { to provide studies and } \\
\text { researches. }\end{array}$ & 3.8 & 0.849 & 0.72 & 0.404 & -1.495 \\
\hline $\begin{array}{l}\text { There is transformation from } \\
\text { tacit knowledge to explicit } \\
\text { knowledge }\end{array}$ & 3.52 & 1.103 & 1.218 & -0.047 & -1.322 \\
\hline $\begin{array}{l}\text { The bank encourages the } \\
\text { students to develop their } \\
\text { knowledge. }\end{array}$ & 4.52 & 0.501 & 0.251 & -0.073 & -2.009 \\
\hline $\begin{array}{l}\text { The bank allows workers to } \\
\text { help with the problem that } \\
\text { faces the bank }\end{array}$ & 3.96 & 0.72 & 0.519 & 0.055 & -1.062 \\
\hline $\begin{array}{l}\text { The bank works on } \\
\text { development of knowledge } \\
\text { that they ha }\end{array}$ & 4.28 & 0.449 & 0.201 & & \\
\hline $\begin{array}{l}\text { The bank provides } \\
\text { mechanisms for receiving } \\
\text { views and suggestions among } \\
\text { employees }\end{array}$ & 3.48 & 0.501 & 0.251 & 0.073 & -2.009 \\
\hline
\end{tabular}

Source: Survey data ,2021 
Table 11: Descriptive statistics for Knowledge Sharing

\begin{tabular}{|l|l|l|l|l|}
\hline & Mean & $\begin{array}{l}\text { Std. } \\
\text { Deviation }\end{array}$ & $\begin{array}{l}\text { Skewnes } \\
\text { s }\end{array}$ & $\begin{array}{l}\text { Kurtosi } \\
\text { s }\end{array}$ \\
\hline $\begin{array}{l}\text { We have specific mechanisms for } \\
\text { sharing lessons learned in learning } \\
\text { activities from team to team }\end{array}$ & 3.55 & 0.897 & 1 & -1.007 \\
\hline $\begin{array}{l}\text { Bank repeatedly emphasizes the } \\
\text { importance of knowledge sharing } \\
\text { in our groups }\end{array}$ & 3.8 & 0.849 & 0.404 & -1.495 \\
\hline $\begin{array}{l}\text { We always analyze unsuccessful } \\
\text { organizational endeavors and } \\
\text { communicate the lessons learned } \\
\text { widely. }\end{array}$ & 3.28 & 0.449 & 1.258 & -1.007 \\
\hline $\begin{array}{l}\text { There is a good deal of } \\
\text { organization conversation that } \\
\text { keeps alive the lessons learned } \\
\text { from history }\end{array}$ & 3.48 & 0.501 & 0.073 & -2.009 \\
\hline $\begin{array}{l}\text { There is facilitating for processes } \\
\text { of consulting between the bank and } \\
\text { the research centers }\end{array}$ & 3.55 & 1.135 & -0.061 & -1.395 \\
\hline $\begin{array}{l}\text { Promote a supportive environment } \\
\text { for knowledge exchange of ideas } \\
\text { among all employees. }\end{array}$ & 4.28 & 0.449 & 1.367 & -1.007 \\
\hline
\end{tabular}

Source: Survey data ,2021 
Table 12: Descriptive statistics for Knowledge Application

\begin{tabular}{|l|r|r|r|r|}
\hline & Mean & $\begin{array}{l}\text { Std. } \\
\text { Deviation }\end{array}$ & Skewness & Kurtosis \\
\hline $\begin{array}{l}\text { There is an initiative to deliver } \\
\text { the knowledge that available to } \\
\text { all employees. }\end{array}$ & 4.52 & 0.695 & 0.001 & -0.919 \\
\hline $\begin{array}{l}\text { The company held different } \\
\text { workshops, lectures and others, } \\
\text { which related to knowledge. }\end{array}$ & 4.01 & 0.501 & -0.073 & -2.009 \\
\hline $\begin{array}{l}\text { The bank has a policy to invite } \\
\text { outside experts to participate on } \\
\text { its workshops and training } \\
\text { programs that related to } \\
\text { knowledge. }\end{array}$ & & & & \\
\hline $\begin{array}{l}\text { The bank encourages its } \\
\text { employees } \\
\text { to benefit from its own } \\
\text { knowledge inventory. }\end{array}$ & 4 & 0.002 & 0.098 & 0.967 \\
\hline
\end{tabular}

Source: Survey data ,2021

Table 13: Descriptive statistics for Proactive

\begin{tabular}{|l|c|c|c|c|c|}
\hline & Mean & $\begin{array}{l}\text { Std. } \\
\text { Deviation }\end{array}$ & Variance & Skewness & Kurtosis \\
\hline $\begin{array}{l}\text { I am able to solve new } \\
\text { and complex problems at } \\
\text { work. }\end{array}$ & 3.48 & 0.501 & 0.251 & 0.073 & -2.009 \\
\hline $\begin{array}{l}\text { When I see something } \\
\text { that I do not like, I am } \\
\text { trying to fix it. }\end{array}$ & 4 & 0.697 & 0.369 & .0 .256 & .0 .222 \\
\hline $\begin{array}{l}\text { I look for opportunities to } \\
\text { make improvements at } \\
\text { work }\end{array}$ & 4.76 & 0.428 & 0.184 & -1.219 & -0.519 \\
\hline $\begin{array}{l}\text { I am trying to find out } \\
\text { more effective ways to } \\
\text { perform my job. }\end{array}$ & 4.52 & 0.501 & 0.251 & -0.073 & -2.009 \\
\hline $\begin{array}{l}\text { I let time take care of } \\
\text { things that I have to do. }\end{array}$ & 4.28 & 0.827 & 0.685 & -0.556 & -1.317 \\
\hline $\begin{array}{l}\text { I design new procedures } \\
\text { or processes for my work } \\
\text { area }\end{array}$ & 4 & 0.695 & 0.484 & 0.003 & -0.919 \\
\hline
\end{tabular}

Source: Survey data ,2021 
Kuruppu K. A.D.T.D., Egodawele M.H.A.

Wayamba Journal of Management 12 (2)

Table 14: Descriptive statistics for Flexible

\begin{tabular}{|c|c|c|c|c|c|}
\hline & Mean & $\begin{array}{l}\text { Std. } \\
\text { Deviation }\end{array}$ & Variance & Skewness & Kurtosis \\
\hline $\begin{array}{l}\text { The changes at work } \\
\text { encourage me }\end{array}$ & 3.72 & 0.449 & 0.201 & -1 & -1.007 \\
\hline $\begin{array}{l}\text { I like to change old ways of } \\
\text { doing things }\end{array}$ & 4 & 0.669 & 0.369 & --1.238 & -1.369 \\
\hline $\begin{array}{l}\text { I am able to perform the job } \\
\text { without knowing the total } \\
\text { picture }\end{array}$ & 2.45 & 1.135 & 1.288 & 0.061 & -1.395 \\
\hline $\begin{array}{l}\text { I am able to work out what } \\
\text { to do when work } \\
\text { instructions are unclear. }\end{array}$ & 3.52 & 0.857 & 0.734 & -1.219 & -0.519 \\
\hline $\begin{array}{l}\text { remain calm and composed } \\
\text { when faced with difficult } \\
\text { circumstances.. }\end{array}$ & 3.24 & 0.428 & 0.184 & 1.219 & -0.519 \\
\hline $\begin{array}{l}\text { When a difficult situation } \\
\text { occurs, I react by trying to } \\
\text { manage the problem. }\end{array}$ & 3.24 & 0.428 & 0.184 & 1.219 & -0.519 \\
\hline $\begin{array}{l}\text { I drop everything and takes } \\
\text { an alternate course of action } \\
\text { to deal with an urgent } \\
\text { problem. }\end{array}$ & 3.48 & 0.501 & 0.251 & 0.073 & -2.009 \\
\hline
\end{tabular}

Source: Survey data ,2021 
Table 15 : Correlation analysis

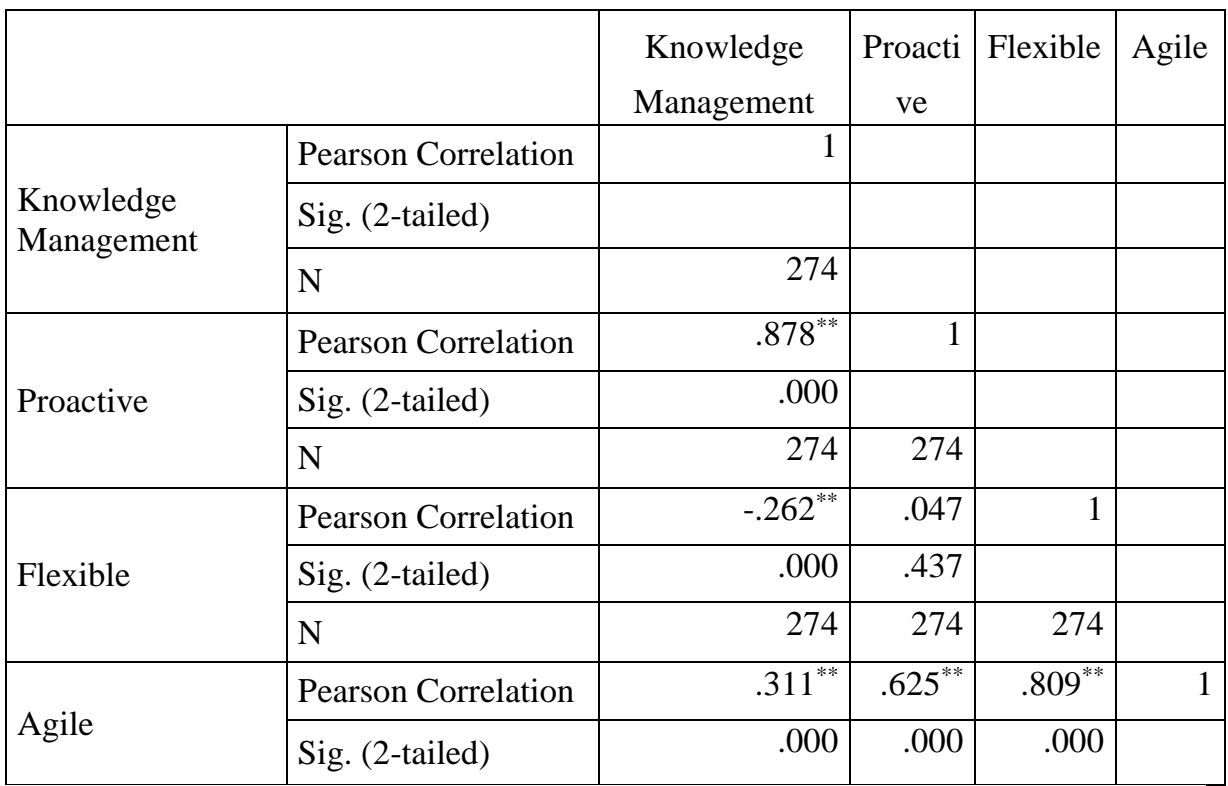

**. Correlation is significant at the 0.01 level (2-tailed).

Source: Survey data ,2021

Table 16: Hypothesis testing

\begin{tabular}{|c|c|c|c|}
\hline \multirow{2}{*}{ Hypotheses } & \multicolumn{2}{|c|}{$\begin{array}{l}\text { Correlation } \\
\text { analysis }\end{array}$} & \multirow[b]{2}{*}{$\frac{0}{\frac{0}{5}}$} \\
\hline & 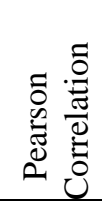 & $\dot{\infty}$ & \\
\hline $\begin{array}{l}\mathrm{H}_{1} \text { : There is a significant relationship between } \\
\text { Knowledge management process ( Creation, } \\
\text { Acquisition, Sharing, and Application) on proactive } \\
\text { agility }\end{array}$ & .878 & .000 & $\begin{array}{l}\text { Fail to } \\
\text { reject }\end{array}$ \\
\hline $\begin{array}{l}\mathrm{H}_{2:} \text { There is a significant relationship between } \\
\text { Knowledge management process ( Creation, } \\
\text { Acquisition, Sharing, and Application) on flexible } \\
\text { agility }\end{array}$ & .662 & .000 & $\begin{array}{l}\text { Fail to } \\
\text { reject }\end{array}$ \\
\hline
\end{tabular}

Source: Survey data ,2021 


\section{REFERENCES}

Aghion, P., \& Griffith, R. (2008). Competition and growth: reconciling theory and evidence. MIT Press.

Alavi, S., \& Wahab, D. (2013). A Review on Workforce Agility. Research Journal Of Applied Sciences, Engineering And Technology, 5(16), 41954199.

https://doi.org/10.19026/rjas et.5.4647

Al-Khouri, A. (2014). Fusing Knowledge Management into the Public Sector: a Review of the Field and the Case of the Emirates Identity Authority. Journal of Knowledge Management, Economics And Information Technology, IV(3), 1-89.

Aliaga, M., \& Gunderson, B. (2002). Interactive statistics. Sage Publications.

Almahamid, S. (2015). The impact of knowledge management process on organizational intelligence: an empirical investigation on Jordanian commercial banks. Jordan Journal of Business

Administration, 11(2), 349 380 .

Almahamid, S. (2018). Knowledge Management Processes and Workforce Agility: A Theoretical Perspective. International
Journal Of Management And Applied Science, 4(7), 28-33.

Ajgaonkar, S., Neelam, N., \& Wiemann, J. (2021). Drivers of workforce agility: a dynamic capability perspective. International Journal Of Organizational Analysis, ahead-ofprint(ahead-of-print). https://doi.org/10.1108/ijoa11-2020-2507

Andreeva, T., \& Kianto, A. (2011). Knowledge processes, knowledgeintensity and innovation: a moderated mediation analysis. Journal Of Knowledge Management, 15(6), 1016 1034.

https://doi.org/10.1108/1367 3271111179343

Athukorala, P., \& Rajapatirana, S. (2000). Liberalization and Industrial Transformation: Lessons from the Sri Lankan Experience. Economic Development And Cultural Change, 48(3), 543-572. https://doi.org/10.1086/4526 $\underline{10}$

Boateng, H., \& Agyemang, F. (2015). The effects of knowledge sharing and knowledge application on service recovery performance. Business Information Review, 32(2), 119-126. 
https://doi.org/10.1177/0266 382115587852

Braun, T., Hayes, B., DeMuth, R., \& Taran, O. (2017). The Development, Validation, and Practical Application of an Employee Agility and Resilience Measure to Facilitate Organizational Change. Industrial And Organizational

Psychology, 10(4), 703-723. https://doi.org/10.1017/iop.2 $\underline{017.79}$

Gaidhani, S., Arora, D., \& Sharma, B. (2019). Understanding the Attitude of Generation Z Towards Workplace. International Journal of Management, Technology And Engineering, IX(1), $\quad 2804-$ 2812.

Gartside, D., Silverstone, Y., \& M. Cantrell, S. (2014). Redesigning HR for Agility. Retrieved 22 September 2021, from https://rainingmag.com/rede signing-hr-for-agility/.

Ghani, S. (2009). Knowledge Management: Tools and Techniques. DESIDOC Journal of Library \& Information

Technology, 29(6), 33-38. https://doi.org/10.14429/djlit .29 .276

Gill, A. (2009). Knowledge management initiatives at a small university. International
Journal Of Educational Management, 23(7), $\quad 604-$ 616. https://doi.org/10.1108/0951 3540910990834

Hatzijordanou, N., Bohn, N., \& Terzidis, O. (2019). A systematic literature review on competitor analysis: status quo and start-up specifics. Management

Review Quarterly, 69(4), 415-458.

https://doi.org/10.1007/s113 01-019-00158-5

Heckler, J., \& Powell, A. (2016). IT and Organizational Agility: A Review of Major Findings. In MWAIS 2016 Proceedings ( $\mathrm{p}$. Retrieved 18 September 2021, from https://aisel.aisnet.org/mwai s2016/3.

Holbeche, L. (2018). Organisational effectiveness and agility. Journal of Organizational

Effectiveness: People And Performance, 5(4), 302-313. https://doi.org/10.1108/joep p-07-2018-0044

Hu, J., \& Liden, R. (2015). Making a Difference in the Teamwork: Linking Team Prosocial Motivation to Team Processes and Effectiveness. Academy $O f$ Management Journal, 58(4), 1102-1127. https://doi.org/10.5465/amj. 2012.1142 
Igbinovia, M., \& Ikenwe, I. (2018). Knowledge management: processes and systems. Information

Impact: Journal of Information And Knowledge Management, 8(3), 26. https://doi.org/10.4314/iijik m.v8i3.3

Khoo, S. (2011). Ethical globalisation or privileged internationalisation?

Exploring global citizenship and internationalisation in Irish and Canadian universities. Globalisation, Societies And Education, 9(3-4), 337-353. https://doi.org/10.1080/1476 7724.2011 .605320

Krancher, O., \& Luther, P. (2021). Software Development in the Cloud: Exploring the Affordances of Platform-asa-Service. In The 36th International Conference of Information Systems (pp. 119). Fort Worth, Texas.

Kucza, T. (2001). Knowledge Management Process Model (p. 111). Espoo: VTT Technical Research Centre of Finland. Retrieved from http://www.vtt.fi/inf/pdf/pub lications/2001/P455.pdf

Mousavizadeh, M., Harden, G., Ryan, S., \& Windsor, J. (2015). Knowledge Management and the Creation of Business Value. Journal of Computer Information Systems, 55(4), 35 https://doi.org/10.1080/0887 4417.2015.11645785

Muduli, A. (2013). Workforce Agility: A Review of Literature. IUP Journal of Management Research, 12(3), 55-65.

Muduli, A. (2016). Exploring the facilitators and mediators of workforce agility: an empirical study. Management Research Review, 39(12), 1567-1586. https://doi.org/10.1108/mrr10-2015-0236

Muduli, A., \& Pandya, G. (2018). Psychological

Empowerment and Workforce Agility. Psychological Studies, 63(3), 276-285. https://doi.org/10.1007/s126 46-018-0456-8

Munteanu, A., Bibu, N., Nastase, M., Cristache, N., \& Matis, C. (2020). Analysis of Practices to Increase the Workforce Agility and to Develop a Sustainable and Competitive Business. Sustainability, 12( 9), 3545 . https://doi.org/10.3390/su 12 $\underline{093545}$

Nonaka, I., \& Takeuchi, H. (1996). The knowledgecreating company: How Japanese companies create the dynamics of innovation. Long Range Planning, 29(4), 592. 
https://doi.org/10.1016/0024 $-6301(96) 81509-3$

Ollusolla, O., Ollodude, Bollanlle, F., \& Olladejjo. (2013). Enhanced customer--based knowledge management system for products generation in banking system. Anale. Seria. Informatica., 11(1), 129 138.

Omotayo, F. (2015). Knowledge Management as an important tool in Organisational Management: A Review of Literature. Library

Philosophy And Practice (EJournal). Retrieved 20 September 2021, from https://digitalcommons.unl.e du/libphilprac/1238/?utm_so urce $=$ digitalcommons.unl.ed u\%2Flibphilprac\%2F1238\& utm medium=PDF\&utm ca mpaign=PDFCoverPages.

Parker, S., Bindl, U., \& Strauss, K. (2010). Making Things Happen: A Model of Proactive

Motivation. Journal Of Management, 36(4), $\quad 827-$ 856.

https://doi.org/10.1177/0149 206310363732

Potdar, P., Routroy, S., \& Behera, A. (2017). Agile manufacturing: a systematic review of literature and implications for future research. Benchmarking: An International Journal, 24(7), 2022-2048. https://doi.org/10.1108/bij06-2016-0100

Qin, R., \& Nembhard, D. (2015). Workforce agility in operations management. Surveys In Operations Research And Management Science, 20(2), 55-69.

https://doi.org/10.1016/j.sor ms.2015.11.001

Rasoulinezhad, E. (2011). Measuring the role of knowledge management processes in the commercial banks of Ira. International Journal of Knowledge Management, 9(4), 353-364.

Rusil, M. R. (2010). Knowledge sharing practice in organization. International Conference on Ethics and Professionalism 2010 (ICEP 2010) (pp. 7988803). Malaysia: Centre For General Studies, UKM and Regional Unit for Social and Human Sciences in Asia and the Pacific (RUSHSAP), UNESCO, Bangkok.

Sarantakos, S. (2005). Social research.

Palgrave

Macmillan

Sherehiy,

B.

(2008). Relationships

between agility strategy, work organization and workforce agility (p. 152). ProQuest. 
Sherehiy, B., \& Karwowski, W. (2014). The relationship between work organization and workforce agility in small manufacturing enterprises. International Journal Of Industrial Ergonomics, 44(3), 466-473.

https://doi.org/10.1016/j.ergon.20 14.01 .002

Spender, J. (1998). Pluralist Epistemology and the Knowledge-Based Theory of the

Firm. Organization, 5(2), 233-256.

https://doi.org/10.1177/1350 50849852005

Storme, M., Suleyman, O., Gotlib, M., \& Lubart, T. (2020). Who is agile? An investigation of the psychological antecedents of workforce agility. Global Business And

Organizational

Excellence, 39(6), 28-38. https://doi.org/10.1002/joe. 2 $\underline{2055}$

Stylianou, V. S. (2016). Investigating the Knowledge Management Culture. Universal Journal of Educational Research, 1515-1521.

Su, G. (2011). Exploring Requirements of Agility for Knowledge Management. In 6th Conference on Professional Knowledge Management: From Knowledge to Action (pp.
371-381).

Innsbruck, Austria.

Vinodh, S., Aravindraj, S., Pushkar, B., \& Kishore, S. (2012). Estimation of reliability and validity of agility constructs using structural equation modelling. International Journal Of Production Research, 50(23), $\quad 6737$ 6745.

https://doi.org/10.1080/0020 7543.2011 .623246

Witherspoon, C., Bergner, J., Cockrell, C., \& Stone, D. (2013). Antecedents of organizational knowledge sharing: a meta- analysis and critique. Journal of Knowledge Management, 17(2), 250277. https://doi.org/10.1108/1367 3271311315204

Yli-Renko, H., Autio, E., \& Sapienza, H. (2001). Social capital, knowledge acquisition, and knowledge exploitation in young technology-based firms. Strategic Management Journal, 22(67), 587-613. https://doi.org/10.1002/smj. 183

Zack, M., McKeen, J., \& Singh, S. (2009). Knowledge management and organizational performance: an exploratory analysis. Journal of Knowledge 
Kuruppu K. A.D.T.D., Egodawele M.H.A.

Wayamba Journal of Management 12 (2)

Management, 13(6), 392-

409.

https://doi.org/10.1108/1367

3270910997088 